The Journal of Academic Librarianship, Vol. 27, No. 6, 2001, pp.473-480.

ISSN: (print 0099-1333) (online 1879-1999)

DOI: $10.1016 /$ S0099-1333(01)00260-9

http://www.elsevier.com/wps/find/journaldescription.cws home/620207/description\#description

http://www.sciencedirect.com/science/journal/00991333

http://www.sciencedirect.com/science?_ob=ArticleURL\&_udi=B6W50-44G8NW7-

B\&_user $=3366836 \&$ _coverDate $=11 \% 2 \mathrm{~F} 30 \% 2 \mathrm{~F} 2001 \&$ \&doc $=10 \&$ fmt $=$ high $\&$ orig $=$ browse $\&$ ssch $=$ doc info(\%23toc\%236556\%232001\%23999729993\%23274030\%23FLA\%23display\%23Volume) \&_cdi=6556\&_sort=d \&_docanchor $=\& \_c t=22 \& \_$acct $=$C000058403\&_version $=1 \&$ urlVersion $=0 \&$ \& userid $=3366836 \& \mathrm{md} 5=59 \mathrm{ff} 3021 \mathrm{cbe} 2$ $\underline{\text { 846f06de55221671e701 }}$

(C) Elsevier.

\title{
Barbarians at the Gates: A Half-Century of Unaffiliated Users in Academic Libraries
}

\section{by Nancy Courtney}

In a 1971 editorial in The Library-College Journal. Marc Brenman remarked on his dismay at losing library privileges when he left a university: "The very concept of being without the use of a library was difficult to grasp, as I had long since taken for granted the library at whatever college or university I happened to be."'1 At first, he related, he was only concerned with the convergence of using scholarly resources nearby but later realized the implication that "in order to be an efficient scholar, one must also be a member of an institution of higher learning" and that "scholarship becomes the exclusive realm of the institution." 2 More than 20 years later, Werner Cohn, a professor emeritus of sociology at the University of British Columbia then living in New York City, wrote about his difficulty in gaining access to resources in the great private universities of the city. He likened the situation to the restrictive policies of European institutions and bemoaned the loss of earlier, more liberal policies; "Until recent years, the American approach contrasted through its openness; everyone in America was presumed worthy of access to the wisdom of the ages. Today, the situation is actually a good deal worse here than in Europe." 3

The point of view of the unaffiliated user is not often represented in the library literature; the arguments for and against opening academic libraries to the use of the public are generally made by librarians who find themselves caught between a professional instinct to provide access to all and the realities of budgets, space, and the needs of their own clientele. This article examines the literature on unaffiliated users' access to academic libraries since the 1950s, when post-war population shifts, emphasis on college-preparatory work at the high school level, and an increase in the college-educated population brought greater numbers of unaffiliated users into the library. 4

\section{0-1980: EXPANSION AND RETRACTION}

\section{Opening the Doors}

John P. Waggoner. Jr., a librarian at Duke University writing in 1964, credited the 19th century public library movement that advocated free access to library services for all with inspiring many university libraries to open their doors to the public. Some, particularly in the Northeastern metro areas where there was greater demand, began to charge fees but many 
remained free. ${ }^{5}$ In general, use by unaffiliated users was minimal and the return in terms of public relations was favorable. H. Vail Deale, in 1958, encouraged academic libraries to contribute to good community relations by offering library privileges to the community and cooperating with local libraries, an undertaking that could be accomplished "with little effort and almost no expense." "Town and gown rapport is exceedingly important in the college or university community," ${ }^{7}$ he wrote, and "any institution is secure only as long as it commands the fullest measure of public understanding and support." ${ }^{8}$ Similarly, Alva Stewart, in 1964, asserted that the liberal policies of her small Methodist college library dispelled the idea that the college is off-limits to outsiders and pointed out that, for many, "the library may be their only point of contact with the college." 9 The library at which she worked extended borrowing privileges to anyone, materials were recalled if needed by the college community. and even reference books were available for 24-hour loan. She reported that most borrowers were high school students, others were students and faculty from other colleges, teachers. clergy, and servicemen. There was not much loss. Waggoner favored extending some privileges to the local community when the practice does not diminish service to the library's primary clientele. He predicted that only a small number will make use of the service but that restrictions may be needed if demand became heavy. ${ }^{10}$

Beyond benevolence and good public relations, some felt that academic libraries had an obligation to serve the public. William C. Archie argued that, while "no one can deny that the college library's first obligation is to its own constituency, the collegiate community," ${ }^{11}$ it was also true that "today's college library also has an obligation to serve the community beyond its own campus." ${ }^{12}$ He promoted the idea of "special-privilege" cards for some high school students, influential or affluent local citizens, and the establishment of Friends groups. For the latter categories, the goal was to encourage support of the library as he did not see any real need of these citizens to use the library. For some, the college library had a particular responsibility to professional people in the local community as it "had more books and periodicals needed by such persons than any other library in the area." ${ }^{13}$ In addition, Waggoner pointed out that colleges and universities often work with the state officials to attract industry to the state and that such industries often locate near educational centers to take advantage of their resources. He saw the exchange of information between higher education and business and industry as mutually beneficial and pointed out that many times practitioners are also engaged as teachers. For this reason, he believed the academic library has a special obligation to provide service to this population, especially when it does not slight the primary clientele. ${ }^{14}$

Various writers proposed granting access to unaffiliated users if they had a legitimate need:

- "We feel that any person who desires information sufficiently to come to the library should be helped,"15

- "The privilege [of using the college library] is seldom denied the student with a definite need," 16 and

- "The academic library should welcome the serious-minded citizen who also wishes to make use of its resources."17 


\section{RESPONSE TO INCREASED DEMAND}

During the 1960s, academic libraries began to feel pressured by the demands created by unaffiliated users. The reasons for the increased demand were many. The increase in population and growth of the suburbs meant that many public libraries were unable to keep pace with the needs of the populace. ${ }^{18}$ Many new colleges and community colleges were established to meet the increased desire for higher education. These new colleges did not have collections of sufficient depth to support their curricula. ${ }^{19}$ The publication explosion meant that both old and new libraries experienced inadequacies in coverage of scientific literature, for which there was a heavy demand. In 1969, E. J. Josey wrote that there was an annual worldwide production of 400,000 books and 35,000 scientific journals. "No one library will be able to acquire this enormous output." ${ }^{20}$ An increase in the number of commuter students posed additional problems. Besides students of traditional college age attending non-residential colleges, commuter students included married veterans and other adult students who "bring to the college campus an adult type of life." ${ }^{21}$ Many colleges began extension courses with little or no provision for library services and students of all types, including those from other colleges or universities home on vacation, preferred to use the libraries that were closest to them or that had better evening and weekend hours. ${ }^{22}$ Increased access to higher education also meant more college graduates whose desire for lifelong learning and access to professional resources encouraged them to make use of their local academic libraries, whether or not they were alumni. ${ }^{23}$

Curriculum expansion also played a part. Colleges began to provide broader courses of study and interdisciplinary courses that required wider reading habits, ${ }^{24}$ and faculty often made course assignments without concern for whether or not their own college library had the necessary resources. ${ }^{25}$

Curricular changes at the secondary school level also contributed to the demand on academic libraries. The post-war space race encouraged a new emphasis on improved secondary school curriculum with more advanced courses, particularly in the sciences. ${ }^{26}$ If colleges and universities were finding it difficult to secure comprehensive scientific materials, the high school libraries were in even worse shape. What is more, they too lacked evening and weekend hours, sending advanced students in search of the nearest college library. ${ }^{27}$ Although academic librarians did not feel a particular obligation to high school students, they generally welcomed students who had a legitimate need and often saw a public relations value and recruitment function in providing services. ${ }^{28}$ Others retracted previously liberal policies to eliminate abuse of borrowing privileges, attract a higher caliber of high school student, and make sure that students exhausted the resources of their high school and public library before coming to the college library. ${ }^{29}$

In $1964 \mathrm{H}$. Vail Deale, whose 1958 article promoted opening the academic library to the public, described the withdrawal of previously generous borrowing privileges at Beloit College as a result of increased usage after building a new facility. Believing that private institutions must support their own constituents first, he urged that libraries adopt restrictive policies while making resources available to those with a "sincere need." ${ }^{30} \mathrm{He}$ also thought that Beloit's liberal policies had contributed to the defeat of the local public library referendum and poor support of the public schools; "We heard the incredible rumor that some citizens voted 'No' because they had convinced themselves that we did not need a new public library now that we had such an attractive one on the campus!"31 
Most reasons for not extending privileges revolve around the concept of "primary clientele." Insufficient facilities and staff made it difficult to provide services for an institution's own members; stretching those resources to include the public would reduce the quality provided to the primary clientele. ${ }^{32}$ Some colleges were unable to provide seating for many of their own students and faculty because of use by outsiders. A conference was held in the Chicago area to consider this problem. ${ }^{33}$ Bailey argued that the attitude that libraries should be open to everyone is a fallacy, that services are not free but incur costs somewhere. ${ }^{34}$ Others pointed out that access is a courtesy, not a right, and that charging fees is acceptable since students have to pay a fee through tuition. ${ }^{35}$

Many discussions of restrictive policies concerned borrowing privileges as it was considered impractical to limit access to reference service unless entrance to the library building was restricted. ${ }^{36}$ In fact, a 1964 Association of College and Research Libraries survey of 1,100 college and university libraries in the United States revealed that 94 percent permitted in-house use to unaffiliated users to some degree and 85 percent allowed circulation privileges. Reasons given for not allowing borrowing were insufficient materials and inadequate staffing. ${ }^{37}$ Of the various classes of users, high school students were the most likely to be restricted, with 32 percent of the libraries responding that they did not permit them; students from other colleges fared somewhat better and teachers, clergy, and professional people even better. ${ }^{38}$

Still, the concept of free access remained. Josey pointed out that residents may argue that they have a right to free access by virtue of their tax support ${ }^{39}$ and later, citing the pressures mentioned above that lead unaffiliated users to seek the services of academic libraries, recommended cooperative acquisitions among libraries in a geographic area, union lists of serials, and joint storage centers. In order to have a national informational system, colleges must be willing to share their resources equally. ${ }^{40}$ David Kaser, in 1974, wrote on the recent proliferation of "universities without walls," external degree programs, and open universities whose students want to use nearby 1ibraries. As librarians particularly feel that society is best served by equal access to information, he proposed models to fund library service nationally for unaffiliated users and discussed the potential problems in trying to accomplish this. ${ }^{41}$ Finally, the Association of College and Research Libraries (ACRL) "Access Policy Guidelines" of 1975, while not actually recommending a particular level of access to unaffiliated users, did highlight ALA's Goals and Objectives and a report of the U.S. National Commission on Libraries and Information Science, both from the same year, that encouraged the provision of library services for all people as an objective of the national interest. ${ }^{42}$

\section{The 1980S: THE BEgINNINGS OF COMPUTERIZATION}

Throughout the 1980s, unaffiliated user access continued to be considered. In a 1988 survey of academic libraries in Virginia. 26 of the 35 library directors who responded said that they felt an obligation to serve the general public. Most cited good public relations as a factor followed by the fact of being state-supported. However, two-thirds of the directors of private institutions also reported feeling an obligation. All of the institutions allowed the public into their library buildings, although two required an application process. Regarding borrowing privileges, 21 of the 35 libraries allowed free borrowing to outside users; these represented two-thirds of the private institutions but only one-half of the public institutions. ${ }^{43}$ A 1984 survey of the State University of New York (SUNY) and City University of New York (CUNY) libraries resulted in responses from 76 of 87 libraries. Of these, 96 percent allowed onsite use of reading materials. 
Ninety-one percent allowed borrowing to others in the system and 71 percent allowed borrowing to those outside the system. ${ }^{44}$ A survey of 10 Atlanta area academic libraries in 1989 reported that all of them provided in-house use to the public whereas only six provided reference assistance. The survey did exclude from its definition of "external user" those affiliated with institutions with which the library had consortial or reciprocal agreements. ${ }^{45}$

The collection of general access, reference, and circulation policies and cooperative agreements of research libraries provided in a 1981 Association of Research Libraries "Spec Kit" on external user services reinforces the notion of service to the "primary clientele." Many of the policies state that sentiment first. The policies also reveal complex systems of access to specific classes of users and increasing numbers of reciprocal agreements, indicating a desire to provide access to those with a perceived legitimate need while at the same time protecting the institution's facilities and collections. ${ }^{46}$ A 1989 "Spec Kit" on the narrower topic of access to visiting scholars noted that 51 percent of the 88 responding libraries belonged to networks or consortia other than OCLC or RLG. Most of these were statewide or local/ regional reciprocal agreements. ${ }^{47}$ Two private universities that otherwise favored limiting service to outsiders still promoted offering assistance to consortia students to retain reciprocal treatment for their own users at other libraries ${ }^{48}$ while another academic library supported a consortium policy that required students to have a reference interview at their local library first. ${ }^{49}$

Arguments against unaffiliated users continued. A Montana State University study of internal files from 1975 through 1977 found that checkouts to external users were distributed throughout the collection and often represented the very subject areas most needed by their own clientele. The loss rate attributable to outside users was more than one-third of the budget for replacements. Possible solutions to the problem were to consider lending materials through interlibrary loan only, so that the borrowing library would be responsible rather than an individual, limiting the number of circulations, and using a collection agency. Reference services were also thought to be strained by external users, although no potential solutions were provided. ${ }^{50}$ Reference service also came under scrutiny in a 1975 survey by the University of British Columbia of reference questions asked over a one-week period at three Canadian university libraries. The researchers found that 14.8 percent of questions asked were from unaffiliated users. Those from other educational institutions (including high schools) represented 38.1 percent of all visitors. Most questions were asked before 5 p.m. and one-third were telephone inquiries. The survey also found that questions from external users took more time to answer than questions from the institutions' own clientele. ${ }^{51}$ Librarians at Georgetown University and George Washington University, both private institutions, described their decision to restrict reference service to external users because they were unable to serve their own clientele fully and felt that a higher percentage of external users need more help than affiliated users. After a certain amount of time on a reference transaction, librarians ascertained the status of the user and withdrew discreetly from helping external users. ${ }^{52}$

High school students received some positive attention from authors during this period. Angie LeClercq reported on a study in Knoxville, Tennessee to assess the need for research service to high schools and provided a model for services to college-bound students. The study found that most high school libraries lack collections to support advanced placement courses, especially periodicals and periodical indexes. ${ }^{53}$ Interestingly, the teachers surveyed thought that most of their students did not need access to academic libraries but that 17 percent could benefit from using an academic library more than half the time. Most teachers felt that students did not use academic libraries for reasons of location, lack of transportation, inconvenient hours, and 
lack of borrowing privileges. ${ }^{54}$ Academic libraries were motivated to work with local schools both to better prepare students who may attend their college or university and to provide good public relations for recruiting purposes. ${ }^{55}$ Ronelle K. H. Thompson and Glenda T. Rhodes, of Augustana College, also promoted academic library services to high school students as a recruiting tool, one that demonstrates to the college administration that the library is "concerned about the institution as a whole. ${ }^{56}$ An opposing viewpoint is provided by librarians at Trinity University, which restricts access to high schools students in the belief that user services to the public undermines support for public libraries. ${ }^{57}$ This view is reinforced by a statement from the Utah College Library Council Guidelines for Community Use of Academic Libraries: "In offering library services to the community, care must be taken to assure that reliance on academic libraries does not encourage other libraries to abrogate their moral and legal obligations of providing adequate collections and services to their own patrons." ${ }^{58}$

As the debate over unaffiliated users continued, other events were taking place that affected all users: the development of electronic substitutes for printed materials and the increasing reliance of libraries on campus computing centers. Online database searching was an important tool of the 1980s, providing faster, more convenient access to traditional abstracts and indexes as well as access to databases that did not exist in printed form. Unfortunately, the economics of online searching were at odds with traditional library budgets. Dial-up searching was billed at a per-minute rate of time online with extra per-record charges for printing results. Both online and printing rates varied by databases, with many scientific and business databases charging very high rates. A lengthy search with many results could easily cost hundreds of dollars. Many libraries offered online searching only to users willing to pay the actual cost of the search, which could not be very well estimated in advance. Librarians became adept at formulating efficient search strategies in the quest for the perfect 30-item search and executing them quickly online. Charging for online searching was controversial as many felt that it limited access to information only to those who could afford it, thus violating a "basic objective of the academic library;" ${ }^{59}$ William Gray Potter observed that "advances in technology are threatening to dilute libraries' ability to provide free and open access to information even as they make possible new, faster, more convenient ways to provide library users with the information they seek." 60

As libraries struggled with an inability to budget for open-ended online searching, the very format made it a luxury service. Potter characterized the ambiguity felt by librarians and others toward emerging formats: "The more removed an information-providing technology is from traditional print publishing, the less evident it is that the information communicated by that technology should be freely and openly available." ${ }^{61}$ In some cases, libraries saved money by canceling printed versions of expensive, lesser-used indexes and abstracts and relying on the online versions. ${ }^{62}$ This did not always mean that the search was provided for free to the end-user and formerly free (printed) resources were now only available at a cost to the user. Many libraries did not perform online searches at all for unaffiliated users and others provided a feebased service to the business community.

CD-ROM technology soon emerged to make database searching available in libraries at a fixed cost for unlimited searches. The cost was usually higher than that for the printed format and the information was leased, not owned. Libraries that chose to cancel printed indexes faced the possibility of missing years of coverage should they ever cancel the CD-ROM product, leading most to maintain multiple formats. Leasing also meant that the same information was paid for repeatedly as part of the annual fee. ${ }^{63}$ Publishers were also cautious, fearing that selling 
or leasing databases directly to libraries would result in lower profits, either from print subscriptions or royalties from commercial online vendors. ${ }^{64}$ Still, the advantages of using electronic databases and their popularity with users persuaded libraries to increase their holdings of electronic resources. The availability of information from several sources "decreased the importance of ownership while increasing that of access." ${ }^{65}$ For unaffiliated users with onsite access to academic libraries, the impact varied. In the early days of CD-ROM database use, access was often limited to one computer workstation. Many libraries had sign-up sheets to deal with patrons competing for popular databases and gave priority or exclusive access to their own clientele. ${ }^{66}$ Even when local area networks emerged and CD-ROM databases were made available to multiple users, many libraries still had too few computer workstations to serve their users and leasing costs were usually higher for larger numbers of simultaneous users.

Paul Metz noted the increasing importance of the academic library's relationship with campus computing staff during this period: "The established role of the campus computing center, the availability of personal computers on campus, the presence or absence of a local area network, become crucial determinants of what the library ought to acquire and how it should deliver what it obtains." ${ }^{67}$ Computing centers often charged for services while libraries tended to fund services centrally in order to provide free access, an attitude that may have seemed "naive or even obstructionist to computing center staff." 68

Lawson Crowe and Susan H. Anthes, writing about the ethical issues of information technology particularly concerning the availability of government information, provided a cautionary note for the end of the decade:

Problems associated with information literacy, the automation of various library functions, possible invasions of user privacy, attempts by federal agencies to restrict access to public documents, and commercialization of information are affected by the expansion of information and the technology for its management. Reduced funding and limited physical space in libraries are also features of the information age. ${ }^{69}$

\section{THE 1990S AND BEYOND: THE INTERNET}

In 1990, Rebecca R. Martin wrote about "The Paradox of Public Service;"70 as the amount of information and the demand for it increases, libraries will be able only to offer a portion of what is available to users. However, she felt that the concept of the "primary user" is contradictory to a library's service ethic, especially given the importance of information in our society. "It is the ethical duty of academic librarians, as librarians and as members of the academic institution, to guarantee that access and to resist any policy or practice that limits or denies it." ${ }^{71}$ Joan Chambers, in the same year, pointed out that for many cities and towns the academic library provided the most extensive services and collections and the information needs of the country could not be met if academic library collections were not available to the public. ${ }^{72}$ In fact, "One reason for including school and public libraries in planning for NREN (the National Research and Education Network) is to ensure their access to the rich resources available in academic libraries. This nation cannot afford academic libraries that are either an unknown or an untapped resource." ${ }^{73}$

Many large urban university libraries consider it part of their mission to serve the needs of the local population but the cost is unaccounted for in budgets that are based on enrolled students. ${ }^{74}$ A survey of public four-year colleges and universities in major metropolitan areas 
showed that all but one of the 49 respondents granted access to the public, about one-half granted circulation privileges to the general public, and well over three-quarters extended circulation privileges to faculty and students of other colleges and universities. Most had the same loan periods and charges for affiliated and unaffiliated users. Among those that did not lend material, a high loss rate by external users was cited as the main reason. ${ }^{75}$ Fred Heath examined the decision by a private university library in a metropolitan area to close to the public during evenings and weekends. Security, the larger numbers of external users drawn to the library's computer systems, not enough seating to serve the university clientele, and the fact that student tuition was approximately 10 times higher than that of nearby state institutions were all considerations. Exceptions were made for graduate students and faculty of affiliated consortia, among others. ${ }^{76}$ A survey of private universities and colleges that are also federal government depositories revealed fairly liberal policies toward outside users even though 70 percent said that their primary mission was to the college or university clientele. Eighty-five percent do not check identification at the door and most that do are in urban areas. Seventy-seven percent said that being private did not conflict with the depository mission to disseminate government information to a wide audience. Eighty-nine percent made no distinction among patrons in reference service. $^{77}$

Several other surveys reported on policies toward external users. A survey of 32 academic libraries in Louisiana revealed that all but one allowed community use and most circulated materials. ${ }^{78}$ Of 10 academic libraries in North Carolina, most did not lend to high school students although most had open access and open circulation policies. ${ }^{79}$ Continued interest in the effect of unaffiliated users on reference services revealed that at Arizona State University unaffiliated users accounted for 35.8 percent of reference patrons and 34.5 percent of the time spent on reference questions. However, they did not find that assisting unaffiliated users took longer amounts of time than assisting their own patrons. ${ }^{80}$ A survey at Georgia State University found that external users represented 10.3 percent of all library patrons but asked 23.9 percent of reference questions. ${ }^{81}$ An informal survey of 25 large publicly funded academic libraries found that the biggest concerns of librarians regarding external user access were reduced access and service to primary users and the sometimes insistent attitudes of external users. ${ }^{82}$ Susan Martin advocated a change in librarians' attitudes toward external users given that questions from primary users were decreasing at the same time that libraries were placing catalogs and other resources on the Internet for all to see. ${ }^{83}$ Librarians who advocate restricting outside users still generally want to make exceptions for those with a special need. As Lloyd M. Jansen wrote, "The importance is in separating the person with a legitimate need for the academic library from the person who is misusing its staff and resources for his or her own convenience." 84

Some California libraries closed to the public in the 1990s. The Moffitt Undergraduate Library at the University of California (UC) at Berkeley closed to all but UC students. faculty, and staff in 1991. Twenty-five percent of its previous users were unaffiliated. Other campus libraries remained open to the public and Moffitt materials were said to be duplicated elsewhere. ${ }^{85}$ The Claremont Colleges libraries and Occidental College library also closed to the public in response to budget cuts and increased demands. ${ }^{86}$

Voters in Jefferson County, Missouri defeated a proposed new public library finding that access to the local Jefferson College library was adequate for their needs, ${ }^{87}$ thus confirming the fears of librarians that academic library service would have a negative effect on local public libraries. On the other hand, a new hybrid type of library is appearing around the country, the 
"joint-use" library between a public and academic library. The city of Westminster, Colorado. and Front Range Community College opened a library that is located on campus but open to the community and is specifically designed to serve both clienteles. ${ }^{88}$ San Jose State University plans to open a joint library with the city of San Jose, despite some opposition by faculty who worry mat materials will be unavailable to faculty and students. ${ }^{89}$

Throughout the 1990s, libraries increased their holdings of computer-based resources, first with stand-alone CD-ROM databases, then local area networks, and finally a significant shift to Web-based databases. The emergence of the Internet also had an impact as libraries began not only to use it as an information resource but also to use Web browsers as a way to manage access to their own locally mounted or CD-ROM databases. The availability of these tools attracted many more external users to academic libraries. California State University, Fullerton, found that 40 to 60 percent of CD-ROM workstation users during peak times were unaffiliated. ${ }^{90}$ The library at Texas Christian University was overrun with users seeking to use new technologies, such as CD-ROMs, a factor in their decision to limit public access. ${ }^{91}$ As users were drawn to the library to use computer resources the printed equivalents became less desirable. In a survey of small liberal arts college libraries, Celia Wall, Roger Haney, and John Griffin found that more than 70 percent had cancelled some subscriptions to abstract and indexing services. Although cost and lack of use were given as the main reasons, 34.5 percent cited online availability as a factor. ${ }^{92} \mathrm{CD}$-ROM was still a new technology at that time, yet several respondents indicated that they were more likely to cancel printed abstracts and indexes in favor of CD-ROM databases. ${ }^{93}$ By 1999, 87 percent of academic libraries surveyed by Library Journal regarding spending on reference materials reported that "they had replaced at least one print product with an electronic version." ${ }^{94}$ Forty-one percent reported spending less for print whereas 80 percent reported spending more on Web-based products. ${ }^{95}$

The public also discovered Internet accessibility at their local academic libraries as universities and colleges were early users of the Internet and the library the one place that was generally open to the public. An article in the Chronicle of Higher Education, in 1998, reported that the general public was overwhelming college libraries by using public computers to access the Internet, including e-mail, chat, and porn sites, and crowding their own users out of use of the machines. ${ }^{96}$ In a letter responding to this article, a library director denied that imposing restrictions on outside users using computers in academic libraries was "an issue of freedom of inquiry or equal access" but one of "unauthorized use of campus resources by external parties" that "should no more be accessible to the public than other campus facilities." He also blamed the problem on librarians who are "not assertive or confrontational" enough to make outside users leave. ${ }^{97}$ In 1999, a survey of 65 academic libraries found that 47.6 percent had no limit on community use of the Internet and 41.5 percent imposed some limits. ${ }^{98}$ The notion that computers in academic libraries are campus resources more than library resources is an important one given that most campus facilities, especially the computing centers, have not traditionally been open to the public, unlike the library. Barbara Jones, writing on intellectual freedom issues in libraries, writes that in disputes with campus network personnel "librarians are professionally obligated to consider the rights of the user, even in situations in which the user is perceived to have abused his or her privileges." 99 She notes that computer center staff are motivated by threats of lawsuits when people misuse the campus networks ${ }^{100}$ and predicts that "access and privacy issues involving campus networks will probably be the biggest intellectual freedom challenge for academic libraries as we move into the next century." 101

One solution to this problem that is most supported by campus computing centers is to 
require "authentication" at library computers, that is, requiring the user to log in with a username and password, essentially restricting use only to affiliated users. Because libraries have increased their cancellations of printed abstracts and indexes in favor of electronic counterparts, this effectively removes those resources from the public's use. Some suggest a few open terminals or librarian-controlled guest logins as compromises. ${ }^{102}$ Authentication also poses a dilemma for federal government depositories as many depository items are now being offered only via the Internet and a number of important documents indexes are commercially produced. In addition to electronic abstracts and indexes, libraries are now increasing their holdings of electronic journals. From 1997 to 1998, the percentage of serial titles in Science Citation Index that were available in separately priced electronic versions increased from 24 to 30 percent and titles in Social Sciences Citation Index from 19 to 24 percent. ${ }^{103}$ In addition, libraries reported that they were increasingly canceling print serial subscriptions and directing serials money to electronic access, not just to online versions but to article on demand services and databases with attached full-text. ${ }^{104}$ Shifting indexing sources and journals themselves to electronic versions brings with it greater control by the vendors, who may insist on licensing agreements that restrict users to a library's own clientele. In Johnson's informal survey of 25 large public academic libraries in 1998, all respondents stressed their compliance with licenses restricting use to their own patrons and, if permitted, to walk-in users. ${ }^{106}$

\section{CONCLUSION}

Despite the debate on the issue of unaffiliated user access to academic libraries, the fact is that most traditionally have allowed onsite use of their materials. From predictions early in the decade that electronic systems would expand access, ${ }^{107}$ we are faced with the possibility of diminished access. The shift from printed to electronic formats, first with abstracting and indexing services and now with journals, combined with the integration of library resources with campus computer networks and the Internet poses a distinct threat to the public's access to information even onsite. It is incumbent upon academic librarians lo be aware of the issues and of the effects that licensing, networking, and collection development decisions have on access to make conscious choices about allowing or denying access to unaffiliated users rather than allowing those choices to be made by others.

\section{NOTES AND REFERENCES}

1. Marc Brenman, "To Use, or Not to Use," Library-College Journal 4 (Summer 1971): 20-21.

2. Ibid., p. 20.

3. Werner Cohn. "Private Stacks, Public Funding," American Libraries 24 (February 1993): 182, 184.

4. This article also provides historical background to a national survey of academic libraries' policies toward unaffiliated users conducted by the author and a colleague in Winter 2001.

5. John P. Waggoner, Jr.. "The Role of the Private University Library," North Carolina Libraries 22 (Winter 1964): 55-57.

6. H. Vail Deale, "Public Relations of Academic Libraries," Library Trends 7 (October 1958): 269-277.

7. Ibid., p. 275.

8. Ibid., p. 270.

9. Alva Stewart, "The New Small College Library," North Carolina Libraries 22 (Winter 1964): 52-54.

10. Waggoner, "Private University," p. 56.

11. William C. Archie, "The College Library and the Community," North Carolina Libraries 22 (Winter 1964): 42-47.

12. Ibid., p. 42. 
13. H. Vail Deale. "Campus vs. Community," Library Journal 89 (April 15, 1964): 1695-1697.

14. Waggoner, "Private University." p. 56.

15. Catherine Clark. "Relation of College Library to Community," Tennessee Librarian 10 (October 1957): 11-14.

16. Jane B. Wilson, "Serving the High School," North Carolina Libraries 22 (Winter 1964): 50-52.

17. Deale. "Public Relations." p. 275.

18. George M. Bailey, "Demands on College and University Library Facilities in Metropolitan Centers," Illinois

Libraries 43 (November 1961): 667-675: Waggoner. "Private University," p. 56.

19. E. J. Josey, "Community Use of Academic Libraries." Library Trends 18 (July 1969): 66-74: Bailey, "Metropolitan Centers." p. 667.

20. Josey. "Community Use," p. 67.

21. Clark, "Relation of College," p. 11.

22. Josey. "Community Use," p. 70; Bailey. "Metropolitan Centers," p. 668.

23. Clark, "Relation of College," p. 12; E. J. Josey, Richard C. Quick, John E. Scott. Edward C. Heintz, Barbara

Lamont, George C. Elser. \& Edward A. Howard. "Community Use of Academic Libraries: A Symposium," College \& Research Libraries 28 (May 1967): 184-202.

24. Josey. "Community Use," p. 68.

25. Ibid., p. 69; Bailey, "Metropolitan Centers." p. 667.

26. Waggoner, "Private University," p. 56; Bailey. "Metropolitan Centers," p. 668.

27. Archie, "College Library," p. 44; Waggoner, "Private University." pp. 56-57.

28. Wilson. "High School," pp. 50-51; Archie, "College Library," p. 45.

29. Philip John Schwartz, "The High School Student and the College Library: Challenge and Response." PNLA Quarterly 34 (Summer 1970): 15-19.

30. Deale, "Campus vs. Community." p. 1697.

31. Ibid., p. 1696.

32. Bailey, "Metropolitan Centers," p. 669.

33. Josey, "Community Use," p. 67.

34. Bailey. "Metropolitan Centers." p. 668.

35. Waggoner, "Private University," pp. 56.

36. Bailey, "Metropolitan Centers." p. 672.

37. Josey, et al.. "Symposium." pp. 185-186.

38. Ibid., p. 187.

39. Ibid., p. 201.

40. Josey. "Community Use," p. 72-73.

41. David Kaser. "Library Access and the Mobility of Users," College \& Research Libraries 35 (July 1974): 280284.

42. Association of College and Research Libraries, "Access Policy Guidelines," College \& Research Libraries News 36 (November 1975): 322-323.

43. Lucretia McCulley \& Dan Ream, "Public Use of Academic Libraries in Virginia," Virginia Librarian 34 (April-June 1988): 9-12.

44. Blanche Judd \& Barbara Scheele, "Community Use of Public Academic Libraries in New York State: A SUNY/CUNY Survey," Bookmark 42 (Winter 1984): 126-134.

45. Ralph E. Russell, Carolyn L. Robison, \& James E. Prather, "External User Access to Academic Libraries." Southeastern Librarian 39 (Winter 1989): 135-138.

46. Association of Research Libraries, External User Services, Spec Kit 73 (Washington D.C.: Association of Research Libraries, 1981).

47. Association of Research Libraries, Onsite Access to Library Collections by Visiting Scholars, Spec Kit 155 (Washington D.C.: Association of Research Libraries. 1989). p. i.

48. Debbie Masters \& Gail Flatness. "Yours, Mine, and Ours: Reference Service and the Non-Affiliated User," Reference Librarian 12 (Spring/Summer 1985): 65-71.

49. Barbara J. Ford \& Craig S. Likness, "Varied Clientele. Service Objectives and Limited Resources: The Academic Library in Transition," Urban Academic Librarian 6-7 (Fall 1988-Spring 1989): 20-24.

50. W. Bede Mitchell, "Formulating a Policy for Academic Library Service to Unaffiliated Borrowers: Some Problems and Considerations," PNLA Quarterly 46 (Spring 1982): 10-17.

51. Association of Research Libraries, "Spec Kit 73," pp. 39-44.

52. Master \& Flatness. "Yours. Mine, and Ours." pp. 66-69.

53. Angie LeClercq, "The Academic Library/High School Library Connection: Needs Assessment and Proposed 
Model," Journal of Academic Librarianship 12 (March 1986): 12-18.

54. Ibid., p. 15.

55. Ibid., pp. 16-17.

56. Ronelle K. H. Thompson \& Glenda T. Rhodes, "Recruitment: A Role for the Academic Library?" College \& Research Libraries News 47 (October 1986): 575-577.

57. Ford \& Likness, "Varied Clientele," p. 21.

58. Association of Research Libraries. "Spec Kit 73." p. 31.

59. Lawson Crowe \& Susan H. Anthes. "The Academic Librarian and Information Technology: Ethical Issues," College \& Research Libraries 49 (March 1988): 123-130.

60. William Gray Potter, "Libraries. Computing Centers, and Freedom of Access," Journal of Academic Librarianship 13 (November 1987): 298a-298b.

61. Ibid., p. 298b.

62. Paul Metz. "Collection Development in Academic Libraries: New Media, New Choices," Journal of Academic Librarianship 13 (November 1987): 298c-298d.

63. Anne Woodsworth, "Computing Centers and Libraries as Cohorts: Exploiting Mutual Strengths," Journal of Library Administration 9 (4) (1988): 21-34.

64. Potter, "Libraries, Computing Centers," p. 298b.

65. Metz. "Collection Development," p. 298d.

66. Russell, "External User Access," p. 137.

67. Metz, "Collection Development." p. 298d.

68. Potter. "Libraries, Computing Centers," p. 298a.

69. Crowe \& Anthes. "Ethical Issues." p 126.

70. Rebecca R. Martin. "The Paradox of Public Service: Where Do We Draw the Line?" College \& Research Libraries 51 (January 1990): 20-26.

71. Ibid., p. 24.

72. Joan Chambers, "Academic Libraries: An Unrecognized National Strength?" College \& Research Libraries News 51 (December 1990): 1086.

73. Ibid.

74. Ralph E. Russell, Carolyn L. Robison, James E. Prather, and Christina E. Carlson, "External User Access to Academic Libraries in Urban/Metropolitan Areas," in Academic Libraries in Urban and Metropolitan Areas: A Management Handbook, edited by Gerard B. McCabe, (New York: Greenwood Press, 1992), pp. 27-32.

75. Eugene S. Mitchell, "General Circulation Policies for Private Citizens: The Practices of Publicly Supported Academic Libraries." in Academic Libraries in Urban and Metropolitan Areas: A Management Handbook, edited by Gerard B. McCabe (New York: Greenwood Press. 1992), pp. 33-44.

76. Fred Heath, "Conflict of Mission: The Midsize Private University in an Urban Environment," in Academic Libraries in Urban and Metropolitan Areas, pp. 15-23.

77. Daniel Blazek, "Private Academe and Public Depositories: Access and Promotion," Journal of Government Information 24 (1997): 285-311.

78. Cinderella W. Hayes \& Hal Mendelsohn, "Community Service in Louisiana Academic Libraries," LLA Bulletin 60 (Winter 1998): 136-139.

79. Barbara Best-Nichols, "Community Use of Tax-Supported Academic Libraries in North Carolina: Is Unlimited Access a Right?" North Carolina Libraries 51 (Fall 1993): 120-125.

80. John S. Spencer \& Luene Dorsey, "Assessing Time Spent on Reference Questions at an Urban University Library," Journal of Academic Librarianship 24 (July 1998): 290-294.

81. Stanley Verhoeven, Elizabeth B. Cooksey, \& Carol A. Hand, "The Disproportionate Use of Reference Desk Service by External Users at an Urban University Library," RO 35 (Spring 1996): 392-397.

82. Peggy Johnson, "Serving Unaffiliated Users in Publicly Funded Academic Libraries," Technicalities 18 (January 1998): 8-11.

83. Susan K. Martin, "A New Kind of Audience," Journal of Academic Librarianship 24 (November 1998$): 469$.

84. Lloyd M. Jansen, "Welcome or Not. Here They Come: Unaffiliated Users of Academic Libraries." Reference Services Review 21 (Spring 1993): 7-14.

85. Ibid., p. 12.

86. Mary Ellen Bobp \& Debora Richey, "Serving Secondary Users: Can It Continue?" College \& Undergraduate Libraries 1 (2) (1994): 1-16.

87. Jeremy Kohler, "College Library Serves as Public Library for Many People," St. Louis Post-Dispatch, 17 April 2000, 1, Lexis-Nexis Academic Universe. 
88. Mike Patty, "Westminster, College Open Book on New Library," Denver Rocky Mountain News, 30 January 1997, 30A, Lexis-Nexis Academic Universe.

89. Maria Alicia Gaura. "Plans are Going Smoothly for Nation's First Joint City-University Library," San Francisco Chronicle, 25 May 2000, A17, Lexis-Nexis Academic Universe; Lisa Guernsey, "Should a College and a City Share a Single Library?" Chronicle of Higher Education, 30 October 1998, A25, Lexis-Nexis AcademicUniverse.

90. Bobp, "Secondary Users," p. 11.

91. Heath, "Conflict of Mission," pp. 19-20.

92. Celia Wall. Roger Haney. \& John Griffin. "Hard Copy versus Online Services: Results of a Survey," College \& Research Libraries 51 (May 1990): 267-276.

93. Ibid., p. 274.

94. Eric Bryant, "Triumph of the Web," Library Journal (November 15, 1999): 4-6.

95. Ibid. p. 5.

96. Lisa Guernsey, "Off-Campus Users Swamp College Libraries, Seeking Access to Web and E-Mail." Chronicle of Higher Education, 31 July 1998: A17. Lexis-Nexis Academic Universe.

97. Steven J. Bell, Letter to the Editor. Chronicle of Higher Education. 18 September 1998: B13, Lexis-Nexis Academic Universe.

98. Beth Hansen Shaw, Managing Electronic Resources: A Survey of Current Practices in Academic Libraries. (Educational Resources Information Center, 1999) (ED434658).

99. Barbara M. Jones. Libraries, Access, and Intellectual Freedom (Chicago: American Library Association. 1999), p. 104.

100. Ibid., p. 13.

101. Ibid., p. 20.

102. Julie Still \& Vibiana Kassabian, "The Mole's Dilemma: Ethical

Aspects of Public Internet Access in Academic Libraries," Internet Reference Services Quarterly 4 (3) (1999): 7-22.

103. Lee Ketcham \& Kathleen Born, "Unsettled Times, Unsettled Prices," Library Journal (April 15, 1997): 42-46;

Lee Ketcham-Van Orsdel \& Kathleen Born. "E-Journals Come of Age," Library Journal (April 15, 1998): 40-45.

104. Ketcham \& Born, "Unsettled Times," p. 42.

105. Jones. "Intellectual Freedom," p. 157.

106. Johnson, "Serving Unaffiliated Users," p. 10.

107. Martin, "Paradox of Public Service," p. 25. 